\title{
Climate Change Effects on Plant Disease: Genomes to Ecosystems
}

\author{
K. A. Garrett, S. P. Dendy, E. E. Frank, \\ M. N. Rouse, and S. E. Travers
}

Department of Plant Pathology, Kansas State University, Manhattan, Kansas 66506; email: kgarrett@ksu.edu; sdendy@ksu.edu; efrank@ksu.edu; mrouse@ksu.edu; travers@ksu.edu

Annu. Rev. Phytopathol.

2006. 44:489-509

First published online as a

Review in Advance on

May 23, 2006

The Annual Review of

Phytopathology is online at

phyto.annualreviews.org

doi: 10.1146/

annurev.phyto.44.070505.143420

Copyright (c) 2006 by

Annual Reviews. All rights

reserved

0066-4286/06/0908-

$0489 \$ 20.00$

\section{Key Words}

climate variability, disease ecology, ecological genomics, epidemiology, global warming

\begin{abstract}
Research in the effects of climate change on plant disease continues to be limited, but some striking progress has been made. At the genomic level, advances in technologies for the high-throughput analysis of gene expression have made it possible to begin discriminating responses to different biotic and abiotic stressors and potential trade-offs in responses. At the scale of the individual plant, enough experiments have been performed to begin synthesizing the effects of climate variables on infection rates, though pathosystemspecific characteristics make synthesis challenging. Models of plant disease have now been developed to incorporate more sophisticated climate predictions. At the population level, the adaptive potential of plant and pathogen populations may prove to be one of the most important predictors of the magnitude of climate change effects. Ecosystem ecologists are now addressing the role of plant disease in ecosystem processes and the challenge of scaling up from individual infection probabilities to epidemics and broader impacts.
\end{abstract}




\section{INTRODUCTION}

IPCC:

Intergovernmental Panel on Climate Change
Eight years ago, Coakley et al. (38) reviewed the implications of climate change for plant disease management in the Annual Review of Phytopathology series. They pointed out several challenges for evaluating the likely effects of climate change. Most experiments considering climate change effects include only one or two of the changing climatic factors, experiments tend to be performed under conditions very different from those in the field, and experiments are generally short-term. But there were already enough results in hand to indicate that climate change could "alter stages and rates of development of the pathogen, modify host resistance, and result in changes in the physiology of host-pathogen interactions." Coakley et al. (38) concluded that the effects of climate change on plant disease management may be less important than changes in land-use patterns, transgenic technologies, and availability of chemical pesticides. Another general conclusion was that the effects of climate change will tend to be different for different pathosystems in different locations, so that generalization is a challenge. Here we consider multiple scales of host-pathogen interaction (Figure 1) and review factors that contribute to determining how and when climate change could have important effects on plant disease.

Since the review by Coakley et al. (38), what has changed? Consensus has continued building among climatologists that global warming is occurring and linked to human activity (62). Scientists have also continued to evaluate the effects of climate change on disease risk across systems (63). More studies of the "fingerprint" of global warming have appeared as interest in the effect grows and as trends become more distinct $(66,85$, $108,120,140)$. More climate change simulation experiments have been put in place (28). Ecologists working outside agricultural systems have turned more attention to the ecology of disease (58). There has been an explo- sion in the development of genomics tools and their application (reviewed in 56). And, with the turn of the millennium, groups such as the UN have reevaluated progress toward societal goals through the formulation of Millennium Development Goals and the Millennium Ecosystem Assessment, while the U.S. National Research Council has formulated a list of Grand Challenges for the environmental sciences, which includes climate change as well as infectious disease (96).

\section{CLIMATE CHANGE}

The Intergovernmental Panel on Climate Change (IPCC), which was jointly established by the World Meteorological Organization (WMO) and the United Nations Environment Program (UNEP) in 1988, has responsibility for assessing information relevant to climate change and summarizing this information for policy makers and the public. It has published major assessment reports most recently in 1995 and 2001 (69). A new assessment is scheduled for publication in 2007, and updated predictions are available in other publications (e.g., 142). Since the 1995 report, there have been a number of advances, including improvements in the Atmosphere-Ocean General Circulation Models (AOGCM) used to predict climate change. Other improvements include better regionalization techniques, a better understanding of the physical processes underlying the models, and better availability of paleoclimate data for evaluating long-term temperature change and historic climate data for evaluating preindustrial atmospheric concentrations of greenhouse gases.

Climate change predictions are based on scenarios that describe greenhouse gas emissions from potential resource use patterns, technological innovations, and demographics. The results from modeling experiments based on these emissions scenarios give a range of predictions, depending on the assumptions quantified by each scenario. Sources of uncertainty in predictions include inability to 

Genome $\rightarrow \begin{gathered}\text { Cellular } \\ \text { processes }\end{gathered} \rightarrow$ Physiology $\longrightarrow \underset{\begin{array}{c}\text { Intrapopulation } \\ \text { dynamics }\end{array}}{ }$

Genome $\rightarrow \begin{gathered}\text { Cellular } \\ \text { processes }\end{gathered} \rightarrow$ Physiology $\longrightarrow$ Intrapopulation

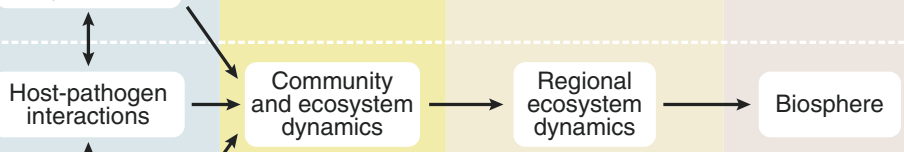

Downregulation of

HR and other genes in tallgrass prairie grass in

response to

precipitation

change (Travers et al.

In preparation)

Peanut gene expression

response to

drought and

Aspergillus (81)

$\begin{array}{ll}\text { Stomatal } & \begin{array}{l}\text { Higher fecundity } \\ \text { Colletotrichum }\end{array} \\ \text { closure and } & \text { gloeosporioides } \\ \text { leaf growth } & \text { under increased } \\ \text { inhibition } & \mathrm{CO}_{2}(29) \\ \text { during } & \end{array}$
drought, e.g.

(32)

$\mathrm{CO}_{2}(29)$

Plant

structural

changes in

response to

$\mathrm{CO}_{2}(117)$

Gene

expression in

plants and

pathogens in

response to

climatic

factors

Multifactor
studies of
climate
change
effects

\section{Better models of} adaptation rates

Better data and models related to dispersal, current

Proteomic and/or metabolomic studies of host and pathogen responses levels of intraspecific diversity, strength of selection under different climate change scenarios, and heritability of traits

\section{Increased}

$\mathrm{CO}_{2}$ increased

fungal pathogen load in prairie

(91)

Heating of montane prairie had mixed effects (121)
Needle blight moving north as precipitation patterns change (148)

P. cinnamomi predicted expansion in Europe due to temperature change (16)
Good models of interspecific interactions like competition and facilitation

Pathogen role in long-term ecological processes
Long-term largescale records of pathogen and host distributions

Models of regional processes that incorporate disease

Data and models regarding dispersal of propagules and vectors
Soybean rust pathogen immigration potentially via hurricane
Integrated multidisciplinary international networks for data collection and synthesis

Figure 1

Examples of potential climate change effects and research needs across biological scales. Arrows indicate propagation of effects from smaller to larger processes, but feedbacks will also link across scales.

fully predict human resource use and incomplete understanding of climate processes. In addition to the predicted increases in temperature for much of the world, changes in extremes are also predicted. For temperature, more frequent extreme high temperatures and less frequent extreme low temperatures are predicted. Likewise, increased intensity of precipitation events is predicted in some regions. Although the IPCC (69) con- cluded in 2001 that there was no compelling evidence that characteristics of tropical and extratropical storms have changed, more recent analyses have concluded that there have been changes in storm patterns in recent years (47, 145), which could influence the global movement of pathogens (26).

Additional predictive variability comes into play for modeling of regional climates (69). All the forms of uncertainty about global 
processes are still a factor, with additional uncertainty due to lack of data from some regions. Meteorological stations in some regions are sparse, particularly in remote regions with complex topography that may produce rapid climatic variation over small areas. While water vapor, evaporation, and precipitation are predicted to increase on average, predictions about increased or decreased precipitation are region specific. In general, precipitation is predicted to increase in both summer and winter in high-latitude regions. In northern mid-latitudes, Antarctica, and tropical Africa, precipitation is predicted to increase in winter. In southern and eastern Asia, precipitation is predicted to increase in summer. Decreases in winter rainfall are predicted for southern Africa, Central America, and Australia. Supplementary material on IPCC websites supplies finer scale predictions. Decreased snow cover and land-ice extent are expected to follow from the trend in increasing temperature.

\section{PLANT RESPONSES TO CLIMATE CHANGE}

\section{Plant Responses in General: At the Level of the Individual}

The direct effects of climate change on individual plants and plant communities may occur in the absence of pathogens, but may also bring about changes in plants that will affect their interactions with pathogens. Changes in plant architecture may affect microclimate and thus risks of infection (27). In general, increased plant density will tend to increase leaf surface wetness and leaf surface wetness duration, and so make infection by foliar pathogens more likely (65). But, of course, how abiotic stress factors interact to affect plants will be key to understanding climate change effects on plants (92); abiotic stress such as heat and drought may contribute to plant susceptibility to pathogens or it may induce general defense pathways which increase resistance.
Elevated $\mathrm{CO}_{2}$ levels tend to result in changed plant structure. At multiple scales, plant organs may increase in size: Increased leaf area, increased leaf thickness, higher numbers of leaves, higher total leaf area per plant, and stems and branches with greater diameter have been observed under elevated $\mathrm{CO}_{2}$ (117). Enhanced photosynthesis, increased water use efficiency, and reduced damage from ozone are also reported under elevated $\mathrm{CO}_{2}$ (139). Since many foliar pathogens benefit from denser plant growth and the resulting more humid microclimate (27), there is the potential for these changes in plant architecture to increase infection rates, all else being equal. But interactions with other changing climatic variables may complicate the effects of elevated $\mathrm{CO}_{2}$. For example, in a California annual grassland, warming, altered precipitation, addition of nitrogen, and elevated $\mathrm{CO}_{2}$ each increased net primary productivity when applied as single factors; but in multifactor treatments, elevated $\mathrm{CO}_{2}$ appeared to suppress the positive effects of the other factors (131).

The effects of elevated temperature on plants will tend to vary greatly throughout the year. During colder parts of the year, warming may relieve plant stress, whereas during hotter parts of the year it may increase stress. When high-temperature stress is exacerbated, plant responses may be similar to those induced by water stress, with symptoms including wilting, leaf burn, leaf folding, and abscission, and physiological responses including changes in RNA metabolism and protein synthesis, enzymes, isoenzymes, and plant growth hormones (34). These changes will certainly affect susceptibility to pathogens, though the wide range of changes may make interactions difficult to predict. As a striking example of the potential effect on the yield of crop plants in response to elevated temperature, rice yield in the Philippines was estimated to decline 10\% for each $1^{\circ} \mathrm{C}$ increase in the minimum temperature during the dry season (110).

Elevated ozone concentrations can change the structure of leaf surfaces, altering the 
physical topography as well as the chemical composition of surfaces, including the structure of epicuticular wax (74). These changes in leaf structure may alter leaf surface properties such as leaf wettability and the ability of leaves to retain solutes, all influencing the ability of pathogens to attach to leaf surfaces and infect (74). Ozone exposure has been proposed to enhance attacks on plants by necrotrophic fungi, root-rot fungi, and bark beetles (123).

Gene expression studies of plant responses to drought stress have expanded rapidly, allowing a more mechanistic understanding of responses and comparison between responses to drought and other stressors. As an example of expression responses, Way et al. (144) found that, under both short- and long-term stress, genes significantly up-regulated included those coding for aldehyde dehydrogenase (associated with osmoregulation), delta pyrroline-5-carboxylate synthetase (with a role in biosynthesis of proline, which acts to protect plant cells from dehydration), and fatty acid alpha-oxidase (involved in repairing stress-induced damage in membranes and regulating fluidity of membrane and permeability to toxic ions). Bray (24) summarized expression responses to drought stress across gene classes. Up-regulated genes included those involved in cellular metabolism, cellular transport, signal transduction, and transcriptional regulation, as well hydrophilic, heatsoluble proteins. Down-regulated genes included those involved in cell wall synthesis, as well as cellulases, and germin-like proteins. These results can be linked to well-known processes occurring at a larger scale within a plant, such as stomatal closure and the inhibition of leaf growth, changes in leaf architecture, and change in root:shoot ratio $(32,34)$.

It is now possible to measure gene expression responses to environmental changes in natural plant populations. For example, Travers et al. (S.E. Travers, M.D. Smith, J. Bai, S.H. Hulbert, J.E. Leach, et al., manuscript submitted) studied the effects of simulated changes in predicted precipitation patterns in tallgrass prairie, where one prediction is for increased intervals between rain events even if total precipitation is not reduced. This experiment focused on the tallgrass prairie dominant plant species Andropogon gerardii. Using maize microarrays, gene expression was studied in the natural population of $A$. gerardii to which rainout exclusion shelters were applied to impose the different precipitation patterns. Increased intervals between precipitation events decreased transcription of genes related to photosynthesis and carbon fixation and increased transcription of a variety of heat shock proteins and kinases. A gene associated with a hypersensitive reaction, HIR1, was significantly downregulated under the treatment with increased intervals, suggesting a defensive cost associated with climate change. Whereas these results are of interest in and of themselves for understanding the tallgrass prairie ecosystem, they also are important as an illustration of advances in microarray technologies to the point where highly variable natural field systems can be sampled and statistically significant differences in gene expression observed in response to climate change simulations.

\section{Host Resistance}

Detecting the effects of drought stress on plant resistance to infection is complicated by the fact that foliar pathogens will tend to have lower infection success under dry conditions (65). But plant pathologists have studied the interactions between pathogen and drought stress at the scale of pathogen populations for some time. For example, Pennypacker et al. (111) found that alfalfa plants inoculated with Verticillium albo-atrum exhibited fewer symptoms under drought stress. For some hostpathogen systems, however, resistance is apparently reduced under drought conditions (34).

Temperature may have important repercussions on the effectiveness of resistance genes, though it may generally be challenging to discriminate between temperature 
effects on host resistance genes versus effects on pathogen virulence. Browder \& Eversmeyer (25) reported that, for the wheatPuccinia recondita system, host-pathogen gene pairs related to resistance responded differently to different temperature ranges. Particular pairings tended to produce low infection rates at specific temperatures and time periods of exposure to these temperatures. Newton \& Young (101) have suggested that resistance mechanisms in barley may be disrupted following drought stress as cells undergo expansion once an adequate water supply is restored. Other systems such as sunflower-broomrape (46) have shown similar temperature sensitivity. In rice, Webb et al. (K. M. Webb, J. Bai, I. Oña, K. A. Garrett, T. W. Mew, C. M. Vera Cruz \& J. E. Leach, manuscript in preparation) found that one bacterial blight resistance gene $(\mathrm{X} a \mathrm{7})$, which confers resistance to Xanthomonas oryzae pv. oryzae, is more effective at high temperatures whereas other bacterial blight resistance genes are less effective with increasing temperature. In this system, there is the potential to determine the molecular basis of the differences in response to temperature (79a).

Elevated $\mathrm{CO}_{2}$ and ozone also have the potential to influence the effectiveness of host resistance (114, 115). Pangga et al. (106) report that high levels of $\mathrm{CO}_{2}$ may prevent induced resistance as plants grow more rapidly. On the other hand, at twice ambient $\mathrm{CO}_{2}$, fecundity of the anthracanose pathogen $\mathrm{Col}$ letotrichum gloeosporioides increased on both resistant and susceptible varieties of Stylosanthes scabra in a controlled environment (29). The potential for accelerated pathogen evolution, if it is found in many pathosystems, may be one of the most important effects of elevated $\mathrm{CO}_{2}$.

Integration of gene expression analyses into studies of plant responses will help to unravel the effects of multiple stressors (92). For example, Luo et al. (81) examined gene expression in a drought-tolerant and Aspergillus-resistant peanut line. As Aspergillus causes significant disease under drought con- ditions, peanuts were examined under control, drought, and Aspergillus/drought treatments. The detected variation in gene expression among treatments indicates that the interaction between host, pathogen, and environment can be studied at the genomic level to increase understanding of processes at larger scales.

More data about the population genetics of defense genes in natural plant populations will be important for determining the potential for adaptation under potential changes in pathogen pressure due to climate change (or other factors). In an unusually extensive study, Thrall \& Burdon (137) have found important variation in both host resistance and pathogen virulence among natural populations. If climate change increases or decreases environmental conduciveness, the shift in selection pressure on the host populations could result in shifts in the diversity of resistance genes present.

\section{Plant Responses in General: At the Level of the Population}

Although much research on plant community responses to climate change has focused on plant species range shifts $(10,88)$, the slow rate of migration of plants from one region to another, combined with land use patterns that fragment plant populations, may make adaptation the more important factor in plant responses to climate change $(41,42)$. But the current state of research in plant adaptation to climate change suggests that plant populations will tend not to have sufficient time to adapt to altered climates (50), so that populations of plant species will be subject to rapid changes in their genetic structure, perhaps especially for plant species with long generation times (72). Even if there is genetic variation present in a population for traits that could support adaptation to a location with altered climate, correlations between traits that do not support selection for the new climate may limit adaptive evolution (50). Also, different populations of the same species may differ 
in both their genetic structure and the extent to which climate change will push the species to its physiological limits (49). As a result of climate change, the abundance of particular species may change rapidly, as species may lose their ability to recover from other perturbations such as diseases, insect herbivores, and climatic extremes within a background of climate changes $(60,72,136)$. Novel plant communities may result (141), with the increased potential for new patterns of host-sharing by pathogens (107). More studies on trait variation related to climate change are needed, along with evaluation of phenotypic plasticity in response to predicted changes in climate.

In agricultural systems, questions about plant population structure are different. There is no direct concern about whether plant populations can successfully migrate through fragmented landscapes, rather the concern is whether farmers will be able to identify and acquire crop genotypes that are adapted to their changing climates $(8,31,45$, $54,122,132,134)$. In traditional agricultural settings, another problem is whether in situ conservation of traditional land races can be meaningfully maintained when local conditions change too rapidly and whether populations of wild crop relatives will be outcompeted by other species better adapted to the new climate. Where seed from variable land races is saved, processes of adaptation will change the selection pressures on these populations and, while new and potentially valuable populations may be generated, much genetic diversity may be lost in subsequent selection to the changing climate. In current crop breeding programs, comparable concerns would include the following: Can climate change result in shorter useful lives for resistance genes, through mechanisms described in other sections of this chapter? Will less emphasis on local adaptation be possible, as conditions change rapidly? Will it be possible to produce varieties that are as productive if they must be adapted to a more variable environment?

\section{PATHOGEN AND VECTOR RESPONSES TO CLIMATE CHANGE}

The range of many pathogens is limited by climatic requirements for overwintering or oversummering of the pathogen or vector. For example, higher winter temperatures of $-6^{\circ} \mathrm{C}$ versus $-10^{\circ} \mathrm{C}$ increase survivorship of overwintering rust fungi (Puccinia graminis) and increase subsequent disease on Festuca and Lolium (113). In the case of Phytophthora infestans, the introduction of multiple mating types, allowing sexual reproduction, increases the ability of the pathogen to overwinter. For pathogens subject to an Allee effect, or destabilizing density-dependent reproduction at low population levels, release from overwintering restrictions may have a much stronger effect than expected (55). Temperature requirements for infection differ among pathogen species. For example, wheat rust fungi differ in their requirements from $2^{\circ}-15^{\circ} \mathrm{C}$ for stripe rust, $10^{\circ}-30^{\circ} \mathrm{C}$ for leaf rust, and $15^{\circ}-35^{\circ} \mathrm{C}$ for stem rust (119).

Similarly, the introduction of new vector species and changes in vector overwintering and oversummering $(52,73,93-95,98-$ 100) and other effects of change on insects (112) may have important effects on pathogen survival, movement, and reproduction. For example, introduction of the glassy-winged sharp shooter has led to increased patterns of infection of grape plants in winter, greatly altering infection rates (3). Interactions between pathogens may also shift with climate change. For cases where timing of infection by different pathogen species is important for determining the outcome of interactions between pathogens, the form of competition or facilitation may be shifted (e.g., 2).

In a review of the effect of climate change on insect herbivory, Bale et al. (11) make many points relevant to plant pathogens, whether insect-vectored or not. They concluded that temperature was the dominant climate factor in terms of direct effects through effects on 
overwintering and the potentially important combination of photoperiod and temperature. They further concluded that there was little evidence of direct effects of $\mathrm{CO}_{2}$ or UVB and that precipitation effects had not been studied sufficiently to draw a general conclusion. Other factors such as acid rain may also influence disease $(6,7,12)$.

Pathogen movement is difficult to study at large scales even in a relatively homogeneous environment, so it is not surprising that few studies have addressed changes in movement with changing climate. But new diagnostic techniques will make it easier to study large numbers of pathogen species over larger scales. For example, diagnostic arrays are being developed to identify large numbers of virus species simultaneously across plant species in agricultural and natural systems (146a). Such approaches can be applied to monitor changes in pathogen populations over time and space, with the potential to revolutionize our understanding of pathogen communities and their movement.

In many cases, temperature increases are predicted to lead to the geographic expansion of pathogen and vector distributions, bringing pathogens into contact with more potential hosts $(10,103)$ and providing new opportunities for pathogen hybridization $(22,23)$. Increased transportation and human movement may act synergistically with temperature changes $(4,48)$. In one of the most detailed analyses of a plant pathogen, Bergot et al. (16) predicted the geographic range expansion of Phytophthora cinnamomi in Europe in response to increased temperatures that would allow for overwintering of this oomycete in new areas. Pathogen range shifts that appear to be associated with climate change are now being reported. Wheat stripe rust is spreading in South Africa in association with changes in rainfall patterns and native grass infection (19). In North America, needle blight caused by Dothistroma septosporum is moving north with increasing temperatures and precipitation (148). Increased pathogen ranges may also have the effect of including expo- sure to reservoir host species that increase prevalence of disease in other adjacent taxa (116). But if some parts of pathogen life cycles are photoperiod sensitive, populations might need to undergo extensive adaptation to make use of extended seasons in temperate areas.

\section{Microbial Interactions}

Soil microbial communities are likely to shift with climate change. Researchers have emphasized that elevated $\mathrm{CO}_{2}$, temperature and nitrogen deposition are important factors in driving soil communities. Soil nitrate concentrations are reduced under elevated $\mathrm{CO}_{2}$ in grassland microcosms (13). In a microcosm experiment by $\mathrm{Hu}$ et al. (64), $\mathrm{CO}_{2}$ increased plant growth, which in turn facilitated plant $\mathrm{N}$ acquisition. Similarly, increasing temperature by $2^{\circ} \mathrm{C}$ in a tallgrass prairie increased plant growth, which facilitated plant uptake of $\mathrm{N}$ and dominance of fungi in the microbial community. These studies suggest that microbial communities may generally experience decreased available $\mathrm{N}$, though plant community composition and soil type will generally have large effects on the type of responses observed (67). Because of the great variation in interactions among microbial species (e.g., $40)$, it is difficult to predict the effect of climate change on the disease-suppressive qualities of soils, both in natural systems and in agricultural systems where farmers are trying actively to increase disease suppressiveness. Recent technological advances such as metagenomic analyses (118) will increase our understanding of microbial dynamics in soil and other environments.

\section{Climate Change Effects on Virulence, Aggressiveness, or Fecundity of Pathogens}

Pathogen evolution rates are determined by the number of generations of pathogen reproduction per time interval, along with other characteristics such as heritability of traits 
related to fitness under the new climate scenario. Temperature governs the rate of reproduction for many pathogens; for example, spore germination of the rust fungus Puccinia substriata increases with increasing temperature over a range of temperatures (135), and the root rot pathogen Monosporascus cannonballus reproduces more quickly at higher temperatures (143). Longer seasons that result from higher temperatures will allow more time for pathogen evolution. Pathogen evolution may also be more rapid when large pathogen populations are present, so increased overwintering and oversummering rates will also contribute. Climate change may also influence whether pathogen populations reproduce sexually or asexually; in some cases, altered temperatures may favor overwintering of sexual propagules (113), thus increasing the evolutionary potential of a population.

Under climate change, pathogens, like plants, may potentially be unable to migrate or adapt as rapidly as environmental conditions change. But most pathogens will have the advantage over plants because of their shorter generation times and, in many cases, the ability to move readily through wind dispersal. Climate variability itself may be an important form of selection: Koelle et al. (78) suggest that particular strains of cholera are selected under more variable environments, such that sensitivity to environmental fluctuations can be considered a phenotypic trait subject to evolution and pathogens may evolve to reduced sensitivity to fluctuations.

\section{HOST-PATHOGEN INTERACTION RESPONSES TO CLIMATE CHANGE}

\section{Gene Expression and Plant Physiology}

Charkraborty et al. (30) have reviewed the effects of $\mathrm{CO}_{2}$ on plant disease. For biotrophic fungi, they found an increase in disease severity for six of ten biotrophic fungi studied, and a decrease for the other four. For 15 necrotrophic fungi studied, they reported that 9 exhibited an increase in disease severity, 4 exhibited a decrease, and 2 remained unchanged. This suggests that predicting effects for unstudied pathosystems will be quite challenging. Some mechanisms of effects of elevated $\mathrm{CO}_{2}$ on plants are fairly well understood, such as reduced stomatal opening and changes in leaf chemistry, so that disease caused by pathogens that infect through stomata, such as Phyllosticta minima, may be reduced (86). But combining the direct effects of elevated $\mathrm{CO}_{2}$ on plants with the effects on disease will make predictions of plant productivity even more challenging. For example, von Tiedemann \& Firsching (139) found that benefits from elevated $\mathrm{CO}_{2}$ counterbalanced negative effects from ozone but did not compensate for the effects of fungal infection. In a study of plant disease in tallgrass prairie, Mitchell et al. $(89,91)$ found that elevated $\mathrm{CO}_{2}$ increased the pathogen load of $\mathrm{C} 3$ grasses, perhaps due to increased leaf longevity and photosynthetic rate. They suggested that one result of climate change for grassland ecosystems could thus be increased pathogen load.

The effects of elevated ozone on disease may not be straightforward to study and predict (123). For rust fungi, as examples, elevated ozone has been found to increase (74) and decrease (139) infection. Karnosky et al. (74) suggested that the effects of ozone on leaf surface characteristics, including wettability, led to increased rust incidence in their study. von Tiedemann \& Firsching (139) also observed that rust-infected plants exhibited symptoms of ozone damage several weeks earlier and with higher severity than uninfected plants.

Plant pathologists have studied the relationship between precipitation and disease for decades. Even without the added impetus of predicting climate change effects, this interaction is of primary importance for predicting disease severity. Decreases in precipitation, or increased intervals between precipitation 
events, have been predicted for a greater geographic area than are increases (69). Drought stress and disease stress may have additive effects on plants, as observed for infection by Xyllela fastidiosa (87), Beet yellows virus (36), and Maize dwarf mosaic virus (102). Other pathogens, such as Macrophomina phaseolina (84) and Septoria musiva causing canker in poplar (83), may cause more deleterious effects on their hosts under drought conditions, though it is unclear whether this is because of increased infection rates under drought or because of increased impacts per infection event. Mayek-Perez et al. (84) suggest that the concentration of carbohydrates in host tissues as a result of drought stress may benefit pathogens such as $M$. phaseolina that can survive in extremely dry soils.

While effects of temperature on disease epidemiology also have a long history of study in agricultural systems, newer work has also addressed temperature effects in a natural montane meadow in Rocky Mountain Biological Station (121). In this study, many pathogens and herbivores were more abundant on plant populations with the longer growing season produced by artificial heating, but some were more abundant in the ambient cooler conditions.

New approaches to the study of preserved specimens may reveal surprising correlations with environmental variables. The ratio of Stagnospora and Septoria species in historic British wheat samples was closely correlated with the levels of environmental $\mathrm{SO}_{2}$ (15). This is also an illustration of how one pathogen might appear to "emerge" in recent decades when it is actually only regaining its historical advantage from the previous century.

\section{Population Biology}

Plant exposure to pathogens may increase under predicted climate change scenarios because of longer growing seasons and expanded ranges for overwintering or oversummering. Both the "absolute range" and the "seasonal range" may be important; for example, wheat leaf rust epidemics in the Great Plains are very different from year to year as a function of whether the pathogen was able to overwinter or was reintroduced from further south. Changes in the timing of conducive temperatures and moisture availability may also alter disease severity; both the likelihood of conducive conditions and the duration of conducive conditions may increase, with nonadditive effects on disease risk. If environmental conditions are more conducive, this may lead not only to more disease in the short run, but also more potential for pathogen evolution. Depending on the life history of the pathogen, new interactions brought about by expanding ranges and exposure to new plant communities could result in rapid pathogen evolution (107).

\section{Plant Disease Management}

Disease management strategies may require adjustment under climate change. Strategies such as delaying planting to avoid a pathogen may become less reliable. And one of the major problems with applications of biological control for plant disease management in the field has been the vulnerability of biocontrol agent populations to environmental variation and environmental extremes $(59,147)$. If appropriate temperature and moisture are not consistently available, biocontrol agent populations may reach densities that are too small to have important effects, and may not recover as rapidly as pathogen populations when conducive conditions recur $(57,61)$.

Models of the risk of movement of invasive pathogens to a new area are typically based on climatic variables such as temperature, rainfall, and humidity (133). Such risk models are of great economic importance when they bear on what trade restrictions may be applied against regions where a pathogen such as Tilletia indica, causal agent of Karnal bunt, is present. For many invasive pathogens, models of climatic conditions and requirements need to be supplemented by information about 
the availability of susceptible hosts and the likelihood of transport of pathogens by trade and other human networks (10).

Johnson (70) defined durable resistance as resistance "that remains effective during its prolonged and widespread use in an environment favorable to the disease." If resistance is "inherently" durable, then climate change may have no influence on its continued efficacy. But "realized durability" will vary depending on the extent to which the conditions defined by Johnson (70) can be avoided through deployment decisions (K. A. Garrett \& R. L. Bowden, manuscript in preparation). Prolonged and widespread exposure of the pathogen population to host populations with a resistance gene is more likely and more important if pathogen overwintering increases along with the number of pathogen generations possible. The frequency with which environments favorable for infection occur will also be an important factor. It is notable that pathogen characteristics that will tend to result in reduced durability of resistance, such as frequent sexual reproduction (85a), will also tend to facilitate adapation to a new climate.

One conclusion about the effects of climate change for disease management is that changes, especially if they lead to greater variability in climate, will tend to add extra uncertainty to decision making. In tropical regions where food security is a particular concern, there may tend to be both greater climate variability and uncertainty and less investment in technologies supporting production of regionally important crops. For example, "orphan crops" (97) of particular regional importance that have received less research attention than dominant temperate crops include plantain, cassava, sweet potato, millets, teff, and quinoa. Information about changing disease-management needs will be particularly important for such crops. In fact, incorporating climatic predictions based on El Niño patterns was found useful for general decision making by subsistence farmers in Zimbabwe (109).

\section{Models for Disease Prediction}

Coakley et al. (38) discussed several approaches that have been used for modeling the effect of climate change on disease. Climate matching is applied by quantifying the climatic features of locations so that the success of an organism in a reference climate can be used to predict the success of that organism in other locations with similar climates where the organism has not yet been introduced or where the climate is expected to change to become similar to the reference climate. Empirical models, such as regression models with climatic variables as predictors and epidemic parameters as response variables, can be used to predict the success of organisms across the range of conditions studied (18), with extrapolation a possibility when the mechanisms of relationship are sufficiently understood. Simulation models are based on theoretical relationships and can be used to predict outcomes under a range of scenarios. Because climate change occurs slowly and variably, it is difficult to study its effects directly. Temporal variability in climate can be used to draw inference about the potential effects of climate change through the argument that temporary effects of a year with unusual climatic features are likely to represent the effects of longer-term changes. More recently, Scherm $(126,127)$ has identified three continuing problems with the application of models for predicting climate change effects on disease. First, model inputs have a high degree of uncertainty $(75,125)$. For example, data on the geographic distribution of disease are still surprisingly difficult to acquire. Second, nonlinear relationships (21) and thresholds in the relationship between climatic variables and epidemiological responses $(104,128)$ make it difficult to collect sufficient data for a clear predictive understanding. Third, the potential for adaptation by plants and pathogens is another complicating factor that is often ignored in models.

At the time of the review by Coakley et al. (38), no studies had been published using 
climate variables generated by the more sophisticated General Circulation Models (GCM). Instead, most studies had been based on fixed changes in temperature or precipitation. Since then, modelers have developed approaches for scaling from the coarse GCM predictions down to the smaller scales at which plant disease epidemics are more typically studied $(14,129,130)$ and for scaling up from small-scale predictions $(5,33,68,79$, 105). Bergot et al. (16) have used a GCM to predict a range expansion of Phytophthora cinnamomi of up to a few hundred km eastward over 100 years, by modeling the temperature of phloem in infected trees to evaluate overwintering probabilities. Chuine et al. (35) have argued for the inclusion of phenology, such as the time of bud and leaf opening or flowering (53), in models of climate effect. Asynchrony between pathogen, vector, and host may be an effect of climate change (43). This could be important for pathosystems such as Fusarium head blight for which there is a specific window of time during which flowers can be infected. Newman (99) has predicted that cereal aphids will decline significantly in southern Britain, but suggests caution in tallying such a prediction as a positive potential outcome from climate change, since many "desirable" insects may experience a similar decline, predictions may vary with region, and, as in most models, potential adaptation by cereal aphids is not evaluated.

\section{Ecosystem Level Effects}

The implications of plant disease at the ecosystem level have rarely been addressed. Malmstrom \& Raffa (82) have addressed incorporating insect and pathogens as "biotic disturbance agents" (76) in models of vegetation change in response to climate. Eviner \& Likens (51) have developed a framework for evaluating likely ecosystem effects for a pathogen and, by extension, the potential ecosystem and "meta-ecosystem" (80) impacts of a pathogen when its epidemiology shifts with a shifting climate. Of course, at this scale, the number of interactions and even types of interactions rapidly increases, and changes in land use patterns will also be important factors (39). But it is relevant to consider Eviner \& Likens' factors for predicting ecosystem effects and how pathogen characterization might shift with climate change: $(a)$ pathogen effect on host survival, physiology, behavior, and/or reproduction; $(b)$ life stages of a host vulnerable to a pathogen; $(c)$ proportion of individuals/biomass infected at a site; (d) spatial extent and distribution of infection; (e) rate of pathogen effects on hosts in relation to rate of response/recovery by hosts or individuals replacing hosts; $(f)$ functional similarity of infected individuals versus replacements; and $(g)$ frequency and duration of pathogen impact. Many of these factors have been addressed in other sections of this review, but the sixth is of particular interest for scaling up predictions to the ecosystem level. It is possible that, even in the extreme event that a plant species should go extinct due to greater pathogen effects resulting from climate change, plant species that replace it could maintain ecosystem function. On the other hand, if climate change produces major shifts in which agricultural species are present in a region, this may result in important changes in nutrient loss from agriculture to surrounding ecosystems. Ultimately, the study of such large-scale processes will be facilitated by remote sensing of plant populations. Although remote sensing technologies have advanced rapidly, there are still challenges to identifying particular plant species and to distinguishing between different types of plant stress in the field (146). Global networking for impact assessment such as the Global Change and Terrestrial Ecosystems Core Project of the International Geosphere-Biosphere Programme will provide context for evaluation (128a).

\section{CONCLUSIONS}

Since climate change effects are challenging to study but of potentially great importance, the topic has been reviewed and 
recommendations put forward almost as frequently as climate change effects have been studied empirically. Thus a number of authors have supplied recommendations for needed research and syntheses. One broad recommendation would be an increased focus on how a changing environment affects evolution $(11,42)$. What pathogen characteristics, such as frequency of generations and proportion of sexual reproduction, affect the rate of adaptation? What host characteristics, such as life span, affect rates of adaptation in both host populations and pathogen populations? Are invasive plant species better able to adapt to climate change and move to new areas rapidly, leaving pathogens behind or at least limiting their evolutionary options through bottlenecks $(1,90,138)$ ?

Closer links between empirical and modeling studies could support more rapid progress in understanding climate change effects. At the smallest scales, understanding trade-offs in plant gene expression in response to different stressors will allow more mechanistic predictions about responses to complex shifts in many climatic variables and perhaps also about the potential for adaptation, once the costs and benefits of expression of particular genes are better understood (20). If these more detailed studies can be developed as modules for inclusion in larger modeling systems, potential problems in calibrating experiments in more controlled environments with field experiments will also need to be addressed (37).

The impact of climate change on disease for a given plant species will depend on the nature of the effects climate change has on both the host and its pathogens (17). Climate change could first affect disease directly by either decreasing or increasing the encounter rate between pathogens and host by changing ranges of the two species. Disease severity should be positively correlated with increases in virulence and aggressiveness of pathogens. However, both of these effects on disease will be mediated by host resistance and encounter rates, which in turn are potentially affected by climate change. Thus a positive effect of climate change on conduciveness to infection or pathogen aggressiveness or virulence could be offset by a concurrent increase in resistance, yielding no net change in disease impact. Species at highest risk for an increase in disease will be those with positive effects of climate change on encounter rates, environmental conduciveness to infection, aggressiveness, or virulence, but with neutral or negative effects on resistance. The effects of climate change on all these traits will ultimately be modified by the evolutionary potential of host and pathogen.

Finally, global climate change will affect plant disease in concert with other global change phenomena. We have discussed the potential effects of introductions of new species, in terms of new hosts that may boost pathogen inoculum levels, new vectors that may alter epidemic dynamics, and new pathogens themselves. Social changes, such as shifts in the availability of agricultural labor, will also change options available for disease management (124). Widespread changes in land-use patterns will alter the potential for populations of plants and plant pathogens (71) to migrate through fragmented landscapes. If agricultural land use decreases in temperate areas and expands in the tropics, policies in temperate areas may support restoration of natural areas or they may support expansion of suburban development (9, 44), while the development of land use policies in tropical areas will face related challenges to maintenance of agricultural productivity and plant biodiversity in a changing world.

\section{SUMMARY POINTS}

1. At the genomic level, advances in technologies for the high-throughput analysis of gene expression have made it possible to begin discriminating host, pathogen, and 
vector responses to different biotic and abiotic stressors and potential trade-offs in responses.

2. At the scale of the individual plant, enough experiments have been performed to begin synthesizing the effects of climate variables on infection rates, though pathosystemspecific characteristics make synthesis challenging.

3. Models of plant disease have now been developed to incorporate more sophisticated climate predictions from General Circulation Models.

4. At the population level, the adaptive potential of plant and pathogen populations may prove to be one of the most important predictors of the magnitude of climate change effects on plant disease, since, for many species, populations will not be able to migrate quickly enough to keep pace with climate change.

5. Ecosystem ecologists are now addressing the role of plant disease in ecosystem processes, with the potential for greater understanding of the large-scale impacts of disease.

\section{ACKNOWLEDGMENTS}

Thanks to R. L. Bowden, P. Garfinkel, H. Gould, E. Jewett, J. E. Leach, A. Saleh, an anonymous reviewer, and members of the KSU Ecological Genomics Community for discussions and comments that improved this manuscript. It is also a pleasure to acknowledge support by the U.S. National Science Foundation under Grants DEB-0130692, DEB-0516046, and EF0525712 (as part of the joint NSF-NIH Ecology of Infectious Disease program), by the Ecological Genomics Initiative of Kansas through NSF Grant No. EPS-0236913 with matching funds from the Kansas Technology Enterprise Corporation, by the Office of Science (Program in Ecosystem Research), U.S. Department of Energy, Grant No. DE-FG02-04ER63892, by the U.S. Agency for International Development for the Sustainable Agriculture and Natural Resources Management Collaborative Research Support Program (SANREM CRSP) under terms of Cooperative Agreement Award No. EPP-A-00-04-00013-00 to the Office of International Research and Development at Virginia Tech and for the Integrated Pest Management CRSP, by the U.S. Department of Agriculture under Grant No. 2002-34103-11746, by the NSF Long Term Ecological Research Program at Konza Prairie, and by The Land Institute. This is Kansas State Experiment Station Contribution No. 06-311-J.

\section{LITERATURE CITED}

1. Agrawal AA, Kotanen PM, Mitchell CE, Power AG, Godsoe W, Klironomos J. 2005. Enemy release? An experiment with congeneric plant pairs and diverse above- and belowground enemies. Ecology 86:2979-89

2. Al-Naimi FA, Garrett KA, Bockus WW. 2005. Competition, facilitation, and niche differentiation in two foliar pathogens. Oecologia 143:449-57

3. Almeida RPP, Wistrom C, Hill BL, Hashim J, Purcell AH. 2005. Vector transmission of Xylella fastidiosa to dormant grape. Plant Dis. 89:419-24

4. Anderson PK, Cunningham AA, Patel NG, Morales FJ, Epstein PR, Daszak P. 2004. Emerging infectious diseases of plants: pathogen pollution, climate change and agrotechnology drivers. Ecol. Evol. 19:535-44 
5. Araújo MB, Pearson RG, Thuiller W, Erhard M. 2005. Validation of species-climate impact models under climate change. Glob. Change Biol. 11:1504-13

6. Asai E, Futai K. 2001. The effects of long-term exposure to simulated acid rain on the development of pine wilt disease caused by Bursaphelenchus xylophilus. For. Pathol. $31: 241-53$

7. Asai E, Futai K. 2005. Effects of inoculum density of pinewood nematode on the development of pine wilt disease in Japanese black pine seedlings pretreated with simulated acid rain. For. Pathol. 35:135-44

8. Ashmore M, Toet S, Emberson L. 2006. Ozone-a significant threat to future world food production? New Phytol. 170:201-4

9. Babbitt B. 2005. Cities in the Wilderness: A New Vision of Land Use in America. Washington, DC: Island Press

10. Baker RHA, Sansford CE, Jarvis CH, Cannon RJC, MacLeod A, Walters KFA. 2000. The role of climatic mapping in predicting the potential geographical distribution of non-indigenous pests under current and future climates. Agric. Ecosyst. Environ. 82:57-71

11. Bale JS, Masters GJ, Hodkinson ID, Awmack C, Bezemer TM, et al. 2002. Herbivory in global climate change research: direct effects of rising temperature on insect herbivores. Glob. Change Biol. 8:1-16

12. Barnard R, Leadley PW, Hungate BA. 2005. Global change, nitrification, and denitrification: a review. Glob. Biogeogr. Cycles 19:GB1007

13. Barnard R, Leadley PW, Lensi R, Barthes L. 2005. Plant, soil microbial and soil inorganic nitrogen responses to elevated $\mathrm{CO}_{2}$ : a study in microcosms of Holcus lanatus. Acta Oecol. 27:171-78

14. Baron C, Sultan B, Balme M, Sarr B, Traore S, et al. 2005. From GCM grid cell to agricultural plot: scale issues affecting modelling of climate impact. Philos. Trans. R. Soc. London Ser. B 360:2095-108

15. Bearchell SJ, Fraaije BA, Shaw MW, Fitt BDL. 2005. Wheat archive links long-term fungal pathogen population dynamics to air pollution. Proc. Natl. Acad. Sci. USA 102:543842

16. Bergot M, Cloppet E, Pérarnaud V, Déqué M, Marçais B, Desprez-Loustau M-L. 2004. Simulation of potential range expansion of oak disease caused by Phytophthora cinnamomi under climate change. Glob. Change Biol. 10:1539-52

17. Boland GJ, Melzer MS, Hopkin A, Higgins V, Nassuth A. 2004. Climate change and plant diseases in Ontario. Can. 7. Plant Pathol. 26:335-50

18. Booth TH, Jovanovic T, Old KM, Dudzinski MJ. 2000. Climatic mapping to identify high-risk areas for Cylindrocladium quinqueseptatum leaf blight on eucalypts in mainland South East Asia and around the world. Environ. Pollut. 108:365-72

19. Boshoff WHP, Pretorius ZA, van Niekerk BD. 2002. Establishment, distribution, and pathogenicity of Puccinia striiformis f. sp. tritici in South Africa. Plant Dis. 86:485-92

20. Bostock RM. 2005. Signal crosstalk and induced resistance: straddling the line between cost and benefit. Annu. Rev. Phytopathol. 43:545-80

21. Bourgeois G, Bourque A, Deaudelin G. 2004. Modelling the impact of climate change on disease incidence: a bioclimatic challenge. Can. F. Plant Pathol. 26:284-90

22. Brasier CM. 2001. Rapid evolution of introduced plant pathogens via interspecific hybridization. BioScience 51:123-33

23. Brasier CM, Cooke DEL, Duncan JM. 1999. Origin of a new Phytophthora pathogen through interspecific hybridization. Proc. Natl. Acad. Sci. USA 96:5878-83

24. Bray EA. 2004. Genes commonly regulated by water-deficit stress in Arabidopsis thaliana. 7. Exp. Bot. 55:2331-41 
This review provides the context for effects of climate change on plant disease from a management perspective in 1999. Our review builds on this analysis.

This review evaluates adaptive potential as a feature that may often prove to be the most important in determining the success of organisms under climate change scenarios.
25. Browder LE, Eversmeyer MG. 1986. Interactions of temperature and time with some Puccinia recondita:Triticum corresponding gene pairs. Phytopathology 76:1286-88

26. Brown JKM, Hovmoller M. 2002. Aerial dispersal of pathogens on the global and continental scales and its impact on plant disease. Science 297:537-41

27. Burdon JJ. 1987. Diseases and Population Biology. New York: Cambridge Univ. Press

28. Chakraborty S. 2006. Potential impact of climate change on plant pathogen interactions. Aust. Plant Pathol. In press

29. Chakraborty S, Datta S. 2003. How will plant pathogens adapt to host plant resistance at elevated $\mathrm{CO}_{2}$ under a changing climate? New Phytol. 159:733-42

30. Chakraborty S, Tiedemann AV, Teng PS. 2000. Climate change: potential impact on plant diseases. Environ. Pollut. 108:317-26

31. Challinor AJ, Wheeler TR, Slingo JM, Hemming D. 2005. Quantification of physical and biological uncertainty in the simulation of the yield of a tropical crop using presentday and doubled $\mathrm{CO}_{2}$ climates. Philos. Trans. R. Soc. London Ser. B 360:2085-94

32. Chaves MM, Maroco JP, Pereira JS. 2003. Understanding plant responses to droughtfrom genes to the whole plant. Funct. Plant Biol. 30:239-64

33. Chelle M. 2005. Phylloclimate or the climate perceived by individual plant organs: What is it? How to model it? What for? New Phytol. 166:781-90

34. Christiansen MN, Lewis CF. 1982. Breeding Plants for Less Favorable Environments. New York: Wiley

35. Chuine I, Cambon G, Comtois P. 2000. Scaling phenology from the local to the regional level: advances from species-specific phenological models. Glob. Change Biol. 6:943-52

36. Clover GRG, Smith HG, Azam-Ali SN, Jaggard KW. 1999. The effects of drought on sugar beet growth in isolation and in combination with beet yellows virus infection. $\mathcal{F}$. Agric. Sci. 133:251-61

37. Coakley SM. 1995. Biospheric change: will it matter in plant pathology? Can. F. Plant Pathol. 17:147-53

38. Coakley SM, Scherm H, Chakraborty S. 1999. Climate change and plant disease management. Annu. Rev. Phytopathol. 37:399-426

39. Dale VH. 1997. The relationship between land-use change and climate change. Ecol. Appl. 7:753-69

40. Davelos AL, Kinkel LL, Samac DA. 2004. Spatial variation in frequency and intensity of antibiotic interactions among streptomycetes from prairie soil. Appl. Environ. Microbiol. 70:1051-58

41. Davis MB, Shaw RG. 2001. Range shifts and adaptive responses to quaternary climate change. Science 292:673-79

42. Davis MB, Shaw RG, Etterson JR. 2005. Evolutionary responses to changing climate. Ecology 86:1704-14

43. Dixon AFG. 2003. Climate change and phenological asynchrony. Ecol. Entomol. 28:38081

44. Dockerty T, Lovett A, Appleton K, Bone A, Sünnenberg G. 2006. Developing scenarios and visualisations to illustrate potential policy and climatic influences on future agricultural landscapes. Agric. Ecosyst. Environ. 14:103-20

45. Doos BR. 2002. The problem of predicting global food production. Ambio 31:417-24

46. Eizenberg H, Plakhine D, Hershenhorn J, Kleifeld Y, Rubin B. 2003. Resistance to broomrape (Orobanche spp.) in sunflower (Helianthus annuus L.) is temperature dependent. F. Exp. Bot. 54:1305-11

47. Emanuel K. 2005. Increasing destructiveness of tropical cyclones over the past 30 years. Nature 436:686-88 
48. Epstein PR. 2001. Climate change and emerging infectious diseases. Microbes Infect. $3: 747-54$

49. Etterson JR. 2004. Evolutionary potential of Chamaecrista fasciculata in relation to climate change. I. Clinal patterns of selection along an environmental gradient in the Great Plains. Evolution 58:1446-58

50. Etterson JR, Shaw RG. 2001. Constraint to adaptive evolution in response to global warming. Science 294:151-54

51. Eviner VT, Likens GE. 2006. Effects of disease on biogeochemical cycling. In Cary Conference XI: Infectious Disease Ecology: The Effects of Ecosystems on Disease and of Disease on Ecosystems, ed. R Ostfeld, F Keesing, V Eviner. New York: Princeton Univ. Press. In press

52. Fabre F, Plantegenest M, Mieuzet L, Dedryver CA, Leterrier JL, Jacquot E. 2005. Effects of climate and land use on the occurrence of viruliferous aphids and the epidemiology of barley yellow dwarf disease. Agric. Ecosyst. Environ. 106:49-55

53. Fitter AH, Fitter RSR. 2002. Rapid changes in flowering time in British plants. Science 296:1689-91

54. Fuhrer J. 2003. Agroecosystern responses to combinations of elevated $\mathrm{CO}_{2}$, ozone, and global climate change. Agric. Ecosyst. Environ. 97:1-20

55. Garrett KA, Bowden RL. 2002. An Allee effect reduces the invasive potential of Tilletia indica. Phytopathology 92:1152-59

56. Garrett KA, Hulbert SH, Leach JE, Travers SE. 2006. Ecological genomics and epidemiology. Eur. 7. Plant Pathol. In press

57. Gibson GJ, Gilligan CA, Kleczkowski A. 1999. Predicting variability in biological control of a plant-pathogen system using stochastic models. Proc. R. Soc. London Ser. B 266:1743-53

58. Gilbert GS. 2002. Evolutionary ecology of plant diseases in natural ecosystems. Annu. Rev. Phytopathol. 40:13-43

59. Grevstad FS. 1999. Factors influencing the chance of population establishment: implications for release strategies in biocontrol. Ecol. Appl. 9:1439-47

60. Gutschick VP, BassiriRad H. 2003. Extreme events as shaping physiology, ecology, and evolution of plants: toward a unified definition and evaluation of their consequences. New Phytol. 160:21-42

61. Hannusch DJ, Boland GJ. 1996. Interactions of air temperature, relative humidity and biological control agents on grey mold of bean. Eur. F. Plant Pathol. 102:133-42

62. Hansen J, Nazarenko L, Ruedy R, Sato M, Willis J, et al. 2005. Earth's energy imbalance: confirmation and implications. Science 308:1431-35

63. Harvell CD, Mitchell CE, Ward JR, Altizer S, Dobson AP, et al. 2002. Climate warming and disease risks for terrestrial and marine biota. Science 296:2158-62

64. Hu S, Chapin FC III, Firestone MK, Field CB, Chiariello NR. 2001. Nitrogen limitation of microbial decomposition in a grassland under elevated $\mathrm{CO}_{2}$. Nature 409:188-91

65. Huber L, Gillespie TJ. 1992. Modeling leaf wetness in relation to plant disease epidemiology. Annu. Rev. Phytopathol. 30:553-77

66. Hughes L. 2000. Biological consequences of global warming: Is the signal already apparent? Trends Ecol. Evol. 15:56-61

67. Hungate BA, Canadell J, Chapin FS III. 1996. Plant species mediate changes in soil microbial $\mathrm{N}$ in response to elevated $\mathrm{CO}_{2}$. Ecology 77:2505-15

68. Huntley B, Green RE, Collingham YC, Hill JK, Willis SG, et al. 2004. The performance of models relating species geographical distributions to climate is independent of trophic level. Ecol. Lett. 7:417-26 
This document summarizes the understanding of the climatology community about the state of current understanding of climate change and is scheduled to be updated in 2007.
69. IPCC. 2001. Climate Change 2001: The Scientific Basis. Contrib. Work. Group I Third Assess. Rep. Intergov. Panel Clim. Change, ed. JT Houghton, Y Ding, DJ Griggs, M Noguer, PJ van der Linden, et al. Cambridge, UK/New York: Cambridge Univ. Press

70. Johnson R. 1984. A critical analysis of durable resistance. Annu. Rev. Phytopathol. 22:309_ 30

71. Jules ES, Kauffman MJ, Ritts WD, Carroll AL. 2002. Spread of an invasive pathogen over a variable landscape: a nonnative root rot on Port Orford cedar. Ecology 83:3167-81

72. Jump AS, Peñuelas J. 2005. Running to stand still: adaptation and the response of plants to rapid climate change. Ecol. Lett. 8:1010-20

73. Kamata N, Esaki K, Kato K, Igeta Y, Wada K. 2002. Potential impact of global warming on deciduous oak dieback caused by ambrosia fungus Raffaelea sp. carried by ambrosia beetle Platypus quercivorus (Coleoptera: Platypodidae) in Japan. Bull. Entomol. Res. 92:119-26

74. Karnosky DF, Percy KE, Xiang B, Callan B, Noormets A, et al. 2002. Interacting elevated $\mathrm{CO}_{2}$ and tropospheric $\mathrm{O}_{3}$ predisposes aspen (Populus tremuloides Michx.) to infection by rust (Melampsora medusae f. sp. tremuloidae). Glob. Change Biol. 8:329-38

75. Katz RW. 2002. Techniques for estimating uncertainty in climate change scenarios and impact studies. Clim. Res. 20:167-85

76. Katz RW, Brush GS, Parlange MB. 2005. Statistics of extremes: modeling ecological disturbances. Ecology 86:1124-34

77. Deleted in proof

78. Koelle K, Pascual M, Yunus M. 2005. Pathogen adaptation to seasonal forcing and climate change. Proc. R. Soc. London Ser. B 272:971-77

79. Lafferty KD, Holt RD. 2003. How should environmental stress affect the population dynamics of disease? Ecol. Lett. 6:654-64

79a. Leach JE, Vera Cruz CM, Bai J, Leung H. 2001. Pathogen fitness penalty as a predictor of durability of disease resistance genes. Annu. Rev. Phytopathol. 39:187-224

80. Loreau M, Mouquet N, Holt RD. 2003. Meta-ecosystems: a theoretical framework for a spatial ecosystem ecology. Ecol. Lett. 6:673-79

81. Luo M, Liang XQ, Dang P, Holbrook CC, Bausher MG, et al. 2005. Microarray-based screening of differentially expressed genes in peanut in response to Aspergillus parasiticus infection and drought stress. Plant Sci. 169:695-703

82. Malmström CM, Raffa KF. 2000. Biotic disturbance agents in the boreal forest: considerations for vegetation change models. Glob. Change Biol. 6:35-48

83. Maxwell DL, Kruger EL, Stanosz GR. 1997. Effects of water stress on colonization of poplar stems and excised leaf disks by Septoria musiva. Phytopathology 87:381-88

84. Mayek-Perez N, Garcia-Espinosa R, Lopez-Castaneda C, Acosta-Gallegos JA, Simpson J. 2002. Water relations, histopathology and growth of common bean (Phaseolus vulgaris L.) during pathogenesis of Macrophomina phaseolina under drought stress. Physiol. Mol. Plant Pathol. 60:185-95

85. McCarty JP. 2001. Ecological consequences of recent climate change. Conserv. Biol. 15:320-31

85a. McDonald BA, Linde C. 2002. Pathogen population genetics, evolutionary potential, and durable resistance. Annu. Rev. Phytopathol. 40:349-79

86. McElrone AJ, Reid CD, Hoye KA, Hart E, Jackson RB. 2005. Elevated $\mathrm{CO}_{2}$ reduces disease incidence and severity of a red maple fungal pathogen via changes in host physiology and leaf chemistry. Glob. Change Biol. 11:1828-36 
87. McElrone AJ, Sherald JL, Forseth IN. 2003. Interactive effects of water stress and xylemlimited bacterial infection on the water relations of a host vine. 7. Exp. Bot. 54:419-30

88. McLachlan JS, Clark JS, Manos PS. 2005. Molecular indicators of tree migration capacity under rapid climate change. Ecology 86:2088-98

89. Mitchell CE. 2003. Trophic control of grassland production and biomass by pathogens. Ecol. Lett. 6:147-55

90. Mitchell CE, Power AG. 2003. Release of invasive plants from fungal and viral pathogens. Nature 421:625-27

91. Mitchell CE, Reich PB, Tilman D, Groth JV. 2003. Effects of elevated $\mathrm{CO}_{2}$, nitrogen deposition, and decreased species diversity on foliar fungal plant disease. Glob. Change Biol. 9:438-51

92. Mittler R. 2006. Abiotic stress, the field environment and stress combination. Trends Plant Sci. 11:15-19

93. Mondor EB, Tremblay MN, Awmack CS, Lindroth RL. 2005. Altered genotypic and phenotypic frequencies of aphid populations under enriched $\mathrm{CO}_{2}$ and $\mathrm{O}_{3}$ atmospheres. Glob. Change Biol. 11:1990-96

94. Mondor EB, Tremblay MN, Lindroth RL. 2004. Transgenerational phenotypic plasticity under future atmospheric conditions. Ecol. Lett. 7:941-46

95. Mondor EB, Tremblay MN, Awmack CS, Lindroth RL. 2004. Divergent pheromonemediated insect behaviour under global atmospheric change. Glob. Change Biol. 10:182024

96. National Research Council. 2001. Grand Challenges in Environmental Sciences. Washington, DC: Natl. Acad. Press

97. Nelson RJ, Naylor RL, Jahn MM. 2004. The role of genomics research in improvement of "orphan" crops. Crop Sci. 44:1901-4

98. Newman J. 2004. Climate change and cereal aphids: the relative effects of increasing $\mathrm{CO}_{2}$ and temperature on aphid population dynamics. Glob. Change Biol. 10:5-15

99. Newman JA. 2005. Climate change and the fate of cereal aphids in Southern Britain. Glob. Change Biol. 11:940-44

100. Newman JA, Gibson DJ, Parsons AJ, Thornley JHM. 2003. How predictable are aphid population responses to elevated $\mathrm{CO}_{2}$ ? F. Anim. Ecol. 72:556-66

101. Newton AC, Young IM. 1996. Temporary partial breakdown of mlo-resistance in spring barley by the sudden relief of soil water stress. Plant Pathol. 45:973-77

102. Olson AJ, Pataky JK, D'Arcy CJ, Ford RE. 1990. Effects of drought stress and infection by maize dwarf mosaic virus in sweet corn. Plant Dis. 74:147-51

103. Olwoch JM, de Rautenbach CJD, Erasmus BFN, Engelbrecht FA, van Jaarsveld AS. 2003. Simulating tick distributions over sub-Saharan Africa: the use of observed and simulated climate surfaces. F. Biogeogr. 30:1221-32

104. Otten W, Bailey DJ, Gilligan CA. 2004. Empirical evidence of spatial thresholds to control invasion of fungal parasites and saprotrophs. New Phytol. 163:125-32

105. Otten W, Gilligan CA. 2006. Soil structure and soil-borne diseases: using epidemiological concepts to scale from fungal spread to plant epidemics. Eur. F. Soil Sci. 57:26-37

106. Pangga IB, Chakraborty S, Yates D. 2004. Canopy size and induced resistance in Stylosanthes scabra determine anthracnose severity at high $\mathrm{CO}_{2}$. Phytopathology 94:221-27

107. Parker IM, Gilbert GS. 2004. The evolutionary ecology of novel plant-pathogen interactions. Annu. Rev. Ecol. Evol. Syst. 35:675-700

108. Parmesan C, Yohe G. 2003. A globally coherent fingerprint of climate change impacts across natural systems. Nature 421:37-42 
109. Patt A, Suarez P, Gwata C. 2005. Effects of seasonal climate forecasts and participatory workshops among subsistence farmers in Zimbabwe. Proc. Natl. Acad. Sci. USA 102:12623-28

110. Peng S, Huang J, Sheehy JE, Laza RC, Visperas RM, et al. 2004. Rice yields decline with higher night temperature from global warming. Proc. Natl. Acad. Sci. USA 101:9971-75

111. Pennypacker BW, Leath KT, Hill RR Jr. 1991. Impact of drought stress on the expression of resistance to Verticillium albo-atrum in alfalfa. Phytopatbology 81:1014-24

112. Percy KE, Awmack CS, Lindroth RL, Kubiske ME, Kopper BJ, et al. 2002. Altered performance of forest pests under atmospheres enriched by $\mathrm{CO}_{2}$ and $\mathrm{O}_{3}$. Nature 420:403-7, 190

113. Pfender WF, Vollmer SS. 1999. Freezing temperature effect on survival of Puccinia graminis subsp. graminicola in Festuca arundinacea and Lolium perenne. Plant Dis. 83:105862

114. Plazek A, Hura K, Rapacz H, Zur I. 2001. The influence of ozone fumigation on metabolic efficiency and plant resistance to fungal pathogens. F. Appl. Bot. 75:8-13

115. Plessl M, Heller W, Payer HD, Elstner EF, Habermeyer J, Heiser I. 2005. Growth parameters and resistance against Drechslera teres of spring barley (Hordeum vulgare L. cv. Scarlett) grown at elevated ozone and carbon dioxide concentrations. Plant Biol. 7:694-705

116. Power AG, Mitchell CE. 2004. Pathogen spillover in disease epidemics. Am. Nat. 164:S79-89

117. Pritchard SG, Rogers HH, Prior SA, Peterson CM. 1999. Elevated $\mathrm{CO}_{2}$ and plant structure: a review. Glob. Change Biol. 5:807-37

118. Riesenfeld CS, Schloss PD, Handelsman J. 2004. Metagenomics: genomic analysis of microbial communities. Annu. Rev. Genet. 38:525-52

119. Roelfs AP, Singh RP, Saari EE. 1992. Rust Diseases of Wheat: Concepts and Methods of Disease Management. Mexico, DF: CIMMYT

120. Root TL, Price JT, Hall KR, Schneider SH, Rosenzweig C, Pounds JA. 2003. Fingerprints of global warming on wild animals and plants. Nature 421:57-60

121. Roy BA, Gusewell S, Harte J. 2004. Response of plant pathogens and herbivores to a warming experiment. Ecology 85:2570-81

122. Runion GB. 2003. Climate change and plant pathosystems-future disease prevention starts here. New Phytol. 159:531-38

123. Sandermann H Jr. 2000. Ozone/biotic disease interactions: molecular biomarkers as a new experimental tool. Environ. Pollut. 108:327-32

124. Savary S, Castilla NP, Elazegui FA, Teng PS. 2005. Multiple effects of two drivers of agricultural change, labour shortage and water scarcity, on rice pest profiles in tropical Asia. Field Crops Res. 91:263-71

125. Scherm H. 2000. Simulating uncertainty in climate-pest models with fuzzy numbers. Environ. Pollut. 108:373-79

126. Scherm H. 2004. Climate change: can we predict the impacts on plant pathology and pest management? Can. F. Plant Pathol. 26:267-73

127. Scherm H, Coakley SM. 2003. Plant pathogens in a changing world. Aust. Plant Pathol. 32:157-65

128. Scherm H, van Bruggen AHC. 1994. Global warming and nonlinear growth-how important are changes in average temperature? Phytopathology 84:1380-84

128a. Scherm H, Sutherst RW, Harrington R, Ingram JSI. 2000. Global networking for assessment of impacts of global change on plant pests. Environ. Poll. 108:333-41 
129. Seem RC. 2004. Forecasting plant disease in a changing climate: a question of scale. Can. 7. Plant Pathol. 26:274-83

130. Seem RC, Magarey RD, ZackJW, Russo JM. 2000. Estimating disease risk at the whole plant level with General Circulation Models. Environ. Pollut. 108:389-95

131. Shaw MR, Zavaleta ES, Chiariello NR, Cleland EE, Mooney HA, Field CB. 2002. Grassland responses to global environmental changes suppressed by elevated $\mathrm{CO}_{2}$. Science 298:1987-90

132. Smith DL, Almaraz JJ. 2004. Climate change and crop production: contributions, impacts, and adaptations. Can. F. Plant Pathol. 26:253-66

133. Stansbury CD, McKirdy SJ. 2002. Forecasting climate suitability for karnal bunt of wheat: a comparison of two meteorological methods. Aust. Plant Pathol. 31:81-92

134. Strand JF. 2000. Some agrometeorological aspects of pest and disease magagement for the 21st century. Agric. For. Meteor. 103:73-82

135. Tapsoba H, Wilson JP. 1997. Effects of temperature and light on germination of urediniospores of the pearl millet rust pathogen, Puccinia substriata var. indica. Plant Dis. $81: 1049-52$

136. Thomas CD, Cameron A, Green RE, Bakkenes M, Beaumont LJ, et al. 2004. Extinction risk from climate change. Nature 427:145-48

137. Thrall PH, Burdon JJ. 2003. Evolution of virulence in a plant host-pathogen metapopulation. Science 299:1735-37

138. Torchin ME, Lafferty KD, Dobson AP, McKenzie VJ, Kuris AM. 2003. Introduced species and their missing parasites. Nature 421:628-30

139. von Tiedemann A, Firsching KH. 2000. Interactive effects of elevated ozone and carbon dioxide on growth and yield of leaf rust-infected versus non-infected wheat. Environ. Pollut. 108:357-63

140. Walther G-R, Post E, Convey P, Menzel A, Parmesan C, et al. 2002. Ecological responses to recent climate change. Nature 416:389-95

141. Walther G-R. 2003. Plants in a warmer world. Perspect. Plant Ecol. Evol. Syst. 6:169-85

142. Wang G. 2005. Agricultural drought in a future climate: results from 15 global climate models participating in the IPCC 4th assessment. Clim. Dyn. 25:739-53

143. Waugh MM, Kim DH, Ferrin DM, Stanghellini ME. 2003. Reproductive potential of Monosporascus cannonballus. Plant Dis. 87:45-50

144. Way H, Chapman S, McIntyre L, Casu R, Xue GP, et al. 2005. Identification of differentially expressed genes in wheat undergoing gradual water deficit stress using a subtractive hybridisation approach. Plant Sci. 168:661-70

145. Webster PJ, Holland GJ, Curry JA, Chang HR. 2005. Changes in tropical cyclone number, duration, and intensity in a warming environment. Science 309:1844-46

146. WestJS, Bravo C, Oberti R, Lemaire D, Moshou D, McCartney HA. 2003. The potential of optical canopy measurement for targeted control of field crop diseases. Annu. Rev. Phytopathol. 41:593-614

146a. Wren JD, Roossinck MJ, Nelson RS, Scheets K, Palmer MW, Melcher U. 2006. Plant virus biodiversity and ecology. PLoS Biol. 4:e80

147. Wong PTW, Mead JA, Croft MC. 2002. Effect of temperature, moisture, soil type and Trichoderma species on the survival of Fusarium pseudograminearum in wheat straw. Aust. Plant Pathol. 31:253-57

148. Woods A, Coates KD, Hamann A. 2005. Is an unprecedented Dothistroma needle blight epidemic related to climate change? BioScience 55:761-69 
R

Contents

Annual Review of Phytopathology

Volume 44, 2006

A Retrospective of an Unconventionally Trained Plant Pathologist:

Plant Diseases to Molecular Plant Pathology

Seiji Ouchi

The Current and Future Dynamics of Disease in Plant Communities

Feremy 7. Burdon, Peter H. Thrall, and Lars Ericson

A Catalogue of the Effector Secretome of Plant Pathogenic Oomycetes

Sophien Kamoun

Genome Packaging by Spherical Plant RNA Viruses

A.L.N. Rao

Quantification and Modeling of Crop Losses: A Review of Purposes

Serge Savary, Paul S. Teng, Laetitia Willocquet, and Forrest W. Nutter, fr.

Nonsystemic Bunt Fungi-Tilletia indica and T. horrida: A Review of

History, Systematics, and Biology

Lori M. Carris, Lisa A. Castlebury, and Blair 7. Goates

Significance of Inducible Defense-related Proteins in Infected Plants

L.C. van Loon, M. Rep, and C.M.F. Pieterse

Coexistence of Related Pathogen Species on Arable Crops in Space and Time

Bruce D. L. Fitt, Yong-Hu Huang, Frank van den Bosch, and fonathan S. West

Virus-Vector Interactions Mediating Nonpersistent and Semipersistent

Transmission of Plant Viruses

fames C.K. Ng and Bryce W. Falk

Breeding for Disease Resistance in the Major Cool-Season Turfgrasses

Stacy A. Bonos, Bruce B. Clarke, and William A. Meyer

Molecular Ecology and Emergence of Tropical Plant Viruses

D. Fargette, G. Konaté, C. Fauquet, E. Muller, M. Peterschmitt, and F.M. Thresh .. 235

Biology of Flower-Infecting Fungi

Henry K. Ngugi and Harald Scherm 
A Model Plant Pathogen from the Kingdom Animalia: Heterodera glycines, the Soybean Cyst Nematode

T.L. Niblack, K.N. Lambert, and G.L. Tylka

Comparative Genomics Reveals What Makes an Enterobacterial Plant

Pathogen

Ian K. Toth, Leighton Pritchard, and Paul R.F. Birch

The Dawn of Fungal Pathogen Genomics

Fin-Rong Xu, You-Liang Peng, Martin B. Dickman, and Amir Sharon

Fitness of Human Enteric Pathogens on Plants and Implications for

Food Safety

Maria T. Brandl

The Role of Ethylene in Host-Pathogen Interactions

Willem F. Broekaert, Stijn L. Delauré, Miguel F.C. De Bolle, and Bruno P.A. Cammue

Phenazine Compounds in Fluorescent Pseudomonas Spp. Biosynthesis and Regulation

Dmitri V. Mavrodi, Wulf Blankenfeldt, and Linda S. Thomashow

Long-Distance RNA-RNA Interactions in Plant Virus Gene

Expression and Replication

W. Allen Miller and K. Andrew White

Evolution of Plant Pathogenicity in Streptomyces

Rosemary Loria, Johan Kers, and Madbumita Foshi

Climate Change Effects on Plant Disease: Genomes to Ecosystems

K.A. Garrett, S.P. Dendy, E.E. Frank, M.N. Rouse, and S.E. Travers

\section{INDEX}

Subject Index

\section{ERRATA}

An online log of corrections to Annual Review of Phytopathology chapters (if any, 1977 to the present) may be found at http://phyto.annualreviews.org/ 